\title{
Auditor's Responsibilities For Investigating And Detecting Illegal Employment Activities By Audit Clients
}

Ronald O. Reed, PhD, CPA, University of Northern Colorado, USA Karen Turner, PhD, CPA, University of Northern Colorado, USA

Allen McConnell, MS, CPA, University of Northern Colorado, USA

\begin{abstract}
Asking the auditor to be responsible for detecting illegal employees is a far reach. This is management's responsibility. However, this paper discusses why the auditor may have an obligation to expand audit procedures to investigate the possibility of illegal hiring practices. When the client is operating in an area or industry where illegal employees are commonly used, then the auditor should use an attitude of professional skepticism and beware of illegal employees being used by the company. Inquiries and observations procedures may indicate potential illegal hiring practices. Also, discussions with management and other employees should be performed as well as a thorough review of board minutes. The procedures performed by the auditor in gaining an understanding of the entity and its environment as well as in the search for illegal acts may identify situations where the hiring of illegal employees is a possibility. One of the main issues raised in the article is the impact on the level of trust that needs to exist between the client and the auditor.
\end{abstract}

Keywords: Illegal immigration and auditing; auditor's responsibility for detecting illegal employment

\section{INTRODUCTION}

Mlegal immigration is one of the hottest topics in U.S. politics today. The issue has supporters on all sides. Congress has repeatedly attempted to pass legislation, but trying to pass a law that attempts to resolve the status of illegal immigrants seems to be evasive. As a result, many illegal immigrants enter the country and are hired by American businesses by using illegal documents.

Numerous articles and headlines highlight the problems of illegal immigrant hiring. The Immigration and Custom Enforcement (ICE) Agency website shows its enforcement efforts. ICE set new records for worksite enforcement in FY 2006 with total arrests being more than seven times greater than in 2002, the last full year of operations for U.S. Immigration and Naturalization Service. However, Table 1 provides numerous examples of worksite infractions since May 1, 2007. To demonstrate the significance of the problem several ICE cases will be explained. At Swift Company on Dec. 12, 2006, more than 1,297 illegal aliens were arrested at Swift meat processing facilities in six states during an enforcement operation that was the result of an investigation of workrelated identity theft. A 10-month investigation culminated in search warrants executed at Swift facilities in Greeley, Colo., Grand Island, Neb., Cactus, Texas, Hyrum, Utah, Marshalltown, Iowa, and Worthington, Minn. Of those arrested, 274 were charged criminally, 129 of them with federal crimes, the others with state crimes. The rest were charged as immigration status violators and were processed for removal. A review of the employment eligibility forms, or I-9s, at Swift facilities nationwide discovered that 30 percent of these documents were suspected of being fraudulent.

On July 10, 2007, ICE arrested 20 employees (Swift II) after executing federal and state warrants in six states. The arrests included a human resources employee, a union official, and current or former Swift employees 
identified by the Federal Trade Commission as suspected identity thieves. The company has not been charged, but the investigation is ongoing.

Table 1: Immigration and Custom Enforcement Workplace Cases

\begin{tabular}{|c|c|c|}
\hline $08 / 28 / 07$ & Cincinnati, $\mathrm{OH}$ & $\begin{array}{l}\text { ICE executes federal criminal search warrants at Koch Foods and arrests more than } 160 \text { on } \\
\text { immigration charges }\end{array}$ \\
\hline $08 / 03 / 07$ & Jackson, MS & $\begin{array}{l}\text { Owner of Tarrasco Steel arrested in ICE probe for hiring illegal alien workers at critical } \\
\text { infrastructure construction sites }\end{array}$ \\
\hline $08 / 02 / 07$ & Boston, MA & $\begin{array}{l}\text { President and managers of New Bedford Manufacturer Indicted on charges of conspiring to } \\
\text { harbor and hire illegal aliens to fulfill lucrative government contracts }\end{array}$ \\
\hline $07 / 23 / 07$ & Dayton, $\mathrm{OH}$ & Centerville business owner sentenced to prison for harboring illegal aliens \\
\hline $07 / 17 / 07$ & Mobile, AL & $\begin{array}{l}\text { Mississippi state employee indicted in driver's license fraud scheme following an ICE-led } \\
\text { investigation }\end{array}$ \\
\hline $07 / 16 / 07$ & Albany, NY & Guilty plea in government's probe of immigration violations at IFCO Systems \\
\hline $07 / 12 / 07$ & Sprinfield, IL & $\begin{array}{l}\text { Former QSI supervisor pleads guilty to harboring illegal aliens, aiding aggravated identity } \\
\text { fraud }\end{array}$ \\
\hline $07 / 12 / 07$ & Greenbelt, MD & $\begin{array}{l}\text { Owners of El Pollo Rico Restaurant charged with employing and harboring aliens, money } \\
\text { laundering and structuring deposits to avoid reporting requirements }\end{array}$ \\
\hline $07 / 11 / 07$ & Washington, DC & ICE makes additional criminal arrests at Swift \& Company plants \\
\hline $07 / 10 / 07$ & Albany, NY & ICE arrests 31 illegal workers in Catskill worksite enforcement operation \\
\hline $06 / 19 / 07$ & San Francisco, CA & $\begin{array}{l}\text { Operator of Bay Area pizza parlors charged in ICE probe for harboring illegal alien workers } \\
\text { from Brazil }\end{array}$ \\
\hline $06 / 18 / 07$ & Kansas City, MO & Roofing companies indicted for money laundering, conspiring to hire illegal aliens \\
\hline $06 / 12 / 07$ & Portland, OR & $\begin{array}{l}\text { Indictments and search warrants target criminal violations by staffing firm for Portland fruit } \\
\text { and vegetable processing plant }\end{array}$ \\
\hline $05 / 31 / 07$ & Springfield, MO & 11 poultry plant employees charged with immigration violations \\
\hline $05 / 24 / 07$ & Springfield, MO & $\begin{array}{l}\text { Eight George's Processing poultry plant employees charged with Social Security fraud, } \\
\text { immigration violations }\end{array}$ \\
\hline $05 / 23 / 07$ & Springfield, MO & $\begin{array}{l}136 \text { workers apprehended after worksite enforcement at George's Processing poultry- } \\
\text { processing plant as part of an ongoing criminal investigation }\end{array}$ \\
\hline $05 / 14 / 07$ & Springfield, IL & 12 plead guilty to fraud following QSI worksite enforcement operation \\
\hline $05 / 10 / 07$ & Little Rock, AK & $\begin{array}{l}\text { ICE arrests } 12 \text { illegal aliens employed by private contractors working at Army National } \\
\text { Guard Base in Little Rock }\end{array}$ \\
\hline
\end{tabular}

The Fresh Del Monte Produce provides another example. The Fresh Del Monte facility was the site of a criminal search warrant executed on June 12, 2007, and a separate, court-ordered immigration enforcement action resulting in the arrest of more than 160 persons illegally present in the United States. On June 27, 2007 a federal grand jury returned indictments against 10 former workers of the Fresh Del Monte Produce in Portland, Ore., facility arrested in conjunction with this ICE investigation. They have been charged with possession of fraudulent immigration documents or Social Security fraud.

Another example is ICE's six-month investigation into the fraudulent use of documents to illegally obtain employment at American Staffing Resources led to these indictments. Possession of a fraudulent immigration document carries a maximum punishment of 10 years imprisonment and a $\$ 250,000$ fine. Social Security fraud carries a maximum punishment of 5 years imprisonment and a $\$ 250,000$ fine. The investigation that produced the search warrants and these indictments are continuing.

These headlines and stories demonstrate the serious issues and problems of our immigration processes, our hiring processes, our laws that regulate hiring eligible workers and the illegal acts that managers and businesses are willing to commit. In many of the cases the companies hired illegal immigrants without knowledge and followed the federal laws to the best of their abilities, but in some of the cases, the company's executives and managers knowingly committed illegal acts. It is likely that in many of these cases, the businesses involved had external 
CPAs associated with their financial statements. If these businesses were publicly-held, it is likely that they and the auditors are impacted by the Sarbanes-Oxley Act of 2001.

This paper will not discuss the pros and cons of illegal immigration nor reasons of why it is occurring., The purpose of this paper is to address the responsibility, if any, the external auditor has in investigating and searching for illegal workers in the client's workforce, which might be construed to be an illegal act committed by the company. The external auditor definitely has a higher level of responsibility if the client has been caught hiring illegal employees by the ICE, if the client has paid a fine or penalty for violations of these laws in the past, or if management acknowledges such violations. However, in most audits, when none of these red flags can be identified, the auditors' responsibilities are not quite as clear. In situations where either management does not knowingly hire illegal employees or may knowingly hire them, but does not communicate that fact to the external auditor, the auditor may have a responsibility to investigate and search for evidence that indicates the possibility of the audit client hiring illegal workers, but even then the evidence may not be overwhelming to convince the auditor that an illegal act has occurred. But to hold the auditor responsible to detect illegal employment by the client is likely to be a far reach.

The issues that will be discussed in the paper are the professional standards that the auditor needs to consider in the course of the engagement that might indicate illegal employment activity and to present a conclusion as to an auditor's responsibility for detecting illegal employees.

The paper is divided into three major sections: overview of federal laws, issues that impact the auditor's responsibility and a conclusion.

\section{OVERVIEW OF FEDERAL LAWS:}

Table 2 identifies a number of federal laws that are in affect that impact illegal immigration. These federal laws identify who can work in the U.S. and what the employer's responsibilities are to hire an employee as well as retention of documentation.

Table 2: Federal Laws on Illegal Immigration

\begin{tabular}{|l|}
\hline Immigration and Nationality Act (1952)Illegal Immigration Reform and Immigrant Responsibility Act (1996) \\
\hline Immigration Reform and Control Act (1986) \\
\hline Immigration Act (1990) \\
\hline Illegal Immigration Reform and Immigrant Responsibility Act (1996) \\
\hline
\end{tabular}

The federal laws clearly identify who can work in the U.S. One might ask the question who can work in the U.S.? Obviously, U.S. citizens are eligible to work. The second eligible group is Lawful Permanent Residents: people that have obtained a permanent Green card that allows them a free status to work. Beyond US citizens and Lawful Permanent Residents, other classifications of individuals are allowed to work in the U.S., but these have very restricted status as to work opportunities. In most cases these groups need to obtain a visa to enter the US. These groups are individual that are non immigrants (vacationers, visitors, etc.), people who claim refugee status and asylum, and people with temporary protected status.

The Immigration Reform and Control Act (IRCA) of 1986 established responsibilities for employers as to who they hire. IRCA made it illegal for public or private employers to knowingly hire employees who may not legally work in the U.S. This act also required the employer to verify the identity and work authorization of every new employee by requiring the completion and retention of the I-9 Form at the time of hiring. Also, IRCA prohibited employers from discriminating against legal citizens in their hiring practices.

The I-9 form has three sections: Section I, the Employee's section, Section II, the Employer's section, and Section III, Updating and Reverification section. The actual I-9 Form is included at the end of paper in Figure 1. 
Employers are required to have all new employees, full-time, part-time, and temporary employees, hired after November 6, 1986 complete Section I of the I-9 Form at the time they are hired.

In Section 1, Employee's part, information is required to be supplied by the employee. One sees that the employee provides their name, address, date of birth, Social Security number and identification of citizenship status. The employee must sign Section 1. The employee may have a translator assist them, but the translator must complete the certification in Section 1. The translator can be a supervisor, another employee, family member or translator for hire.

The employer must complete Section II of the I-9 Form within three days of hire. This section documents the verification of the employees' documentation and indicates the employee's legal status. In Section 2, Employer section, the employer is verifying employee identity and employment eligibility status. At the end of the I-9 Form there is a list of acceptable identifiable and eligibility documents.

In general, the employer has the responsibility to verify identity and eligibility, but IRCA provides for a variety of documents that will suffice, which one can see from the lists. The employer should never reject documents that appear to be reasonably valid and relate to the individual presenting them. However, nothing prohibits the employer from reverifying work authorization.

The employer is required to maintain the I-9 Forms. It can retain the documents in a variety of forms: paper, microfiche or microfilm and, in today's electronic age, in an electronic format.

Besides these sight verifications, the employer may receive a notice from the Social Security Administration (SSA) indicating a "no match" or problem with the social security number provided by the employer for employees. The employer should follow procedures such as checking its own records for errors; discussing the issue with the employee to clarify the problem; asking the employee to contact the SSA; asking the employee to complete a new I-9; and, if the matter cannot be resolved, possibly terminating the employee. However, the employer has many options, and nothing definitive that clearly resolves the issue.

Currently, there is a program, the Employment Verification Program, which was authorized by Illegal Immigration Reform and Immigrant Responsibility Act of 1996 that cuts across a variety agencies that are involved in the issue of employment: SSA, Department of Homeland Security, and the U.S. Citizenship and Immigration Services (USCIS). The states and employers can voluntarily participate in the program. The program allows states and employers to verify the employment authorization for new hires by entering the information on the I-9 forms, and this is matched against the databases of the various agencies. If the information is appropriate and matches, the employer gets instant verification and the employee is considered having a legal status. Mismatches result in further investigation into the problem and resolution should be reached before hiring the individual. Again, this is voluntary and not all states or employers participate in the program.

\section{EXTERNAL CPAS/AUDITOR'S RESPONSIBILITIES FOR INVESTIGATING AND DETECTING ILLEGAL EMPLOYEES}

The external auditor (the auditor) is mainly responsible for rendering an opinion on the fairness of the financial statements. In all audits, the auditor has a responsibility for understanding the entity and the environment in which the entity operates. This understanding assists the auditor in assessing where material misstatements may occur. Furthermore, the auditor must investigate potential and existing illegal acts by the clients and the financial uncertainties that may result because of them. Intertwined in these issues is the whole area of management integrity and how forthcoming is management and their commitment to hire legal employees. The auditor's direct responsibilities for detecting illegal employees are likely to be negligible and would depend upon the auditor's knowledge of a potential or current existence of illegal employment by the client because of the inherent risk within the industry. If the auditor has knowledge that the client is likely to hire or has hired illegal employees in the past, then the auditor has additional responsibilities. 

employees:

There are four major areas that impact the auditor in this area of responsibilities for detecting illegal

1. Risk assessment procedures and understanding the entity and its environment, including internal control (AU 314);

2. Investigating for possible illegal acts by the client (AU 317);

3. Dealing with possible concerns with management's integrity; and

4. Determining possible financial implications to the client as a result of illegal acts and disruption of business because of employing illegal employees.

\section{RISK ASSESSMENT PROCEDURES AND UNDERSTANDING THE ENTITY AND ITS ENVIRONMENT}

In today's audit, an essential aspect of performing an audit in accordance with generally accepted auditing standards is obtaining an understanding of the entity and its environment. The AICPA's Professional Standards section AU 314, Risk Assessment Procedures and Understanding the Entity and Its Environment, addresses this issue. In particular, this understanding establishes a frame of reference within which the auditor plans the audit and exercises professional judgment about assessing risks of material misstatement of the financial statements and responding to those risks throughout the audit. The auditor must identify areas where special audit consideration may be necessary, such as industries where illegal employees more usually employed.

When one examines the many ICE articles, one can see that certain industries are very likely to use illegal employees in the workforce, such as in the meat packing, construction, agricultural, leisure (hotels), and cleaning services. If the audit client's industry is likely to use illegal employees, the auditor should be aware of this situation and perform additional procedures to determine whether an illegal act is present and needs to discuss this possibility with management. The results may need to be disclosed along with a determination of possible financial impact.

The members of the audit team, including the auditor with final responsibility for the audit, should discuss with the audit team the susceptibility of the entity's hiring practices and to be alert for these problems. This discussion could be held concurrently with the discussion among the audit team that is specified by to discuss the susceptibility of the entity's financial statements to illegal acts.

The auditor should use professional judgment to determine the extent of the understanding required of the entity and its environment, including its internal control. The auditor's primary consideration is whether the understanding that has been obtained is sufficient to assess risks of material misstatement of the financial statements and to design and perform further audit procedures.

The auditor should perform the following risk assessment procedures to obtain an understanding of the entity and its environment, including its internal control:

A. Inquiries of management and others within the entity

B. Analytical procedures

C. Observation and inspection

In addition, the auditor might perform other procedures where the information obtained may be helpful in identifying risks of material misstatement or illegal hiring practices. For example, in cooperation with the entity, the auditor may consider making inquiries of others outside the entity such as the entity's external legal counsel. Reviewing information obtained from external sources such as reports by regulatory agencies such as the SSA or the Employment Verification Program or industry publications may also be useful in obtaining information about the entity.

Although much of the information the auditor obtains by inquiries can be obtained from management and those responsible for financial reporting, inquiries of others within the entity, such as human resources, production and internal audit personnel, and other employees with different levels of authority, may be useful in providing the auditor with a different perspective in identifying risks of material misstatement or illegal hiring practices. In determining others within the entity to which inquiries may be directed, or the extent of those inquiries, the auditor 
should consider what information may be obtained that might help the auditor in identifying risks of material misstatement or illegal hiring practices. For example, the auditor inquiries directed toward those charged with governance may help the auditor understand the environment in which the financial statements are prepared, or inquiries directed toward in-house legal counsel may relate to such matters as litigation and compliance with specific work eligibility laws and regulations.

Of course, analytical procedures should be performed to assess the viability of the payroll in relation to amounts normally paid for similar skill levels and payroll taxes both withheld and later remitted to the respective state and federal agencies.

Other risk assessment procedures would include observation and inspection and may support inquiries of management and others. These procedures may provide information about the entity and its environment about hiring illegal employees. Such audit procedures ordinarily include:

- $\quad$ Observation of entity activities, operations, and employees

- Inspection of documents, records, and internal control manuals related to hiring practices,

- $\quad$ Reading reports prepared by those charged with governance (such as minutes of board of directors' meetings), and internal audit, and

- Visits to the entity's premises and plant facilities.

The auditor's judgment is in play throughout the audit and definitely occurs in the evaluation of the risk assessment procedures. In many situations, unless the management and employees clearly state that illegal hiring practice are present, it will be difficult to obtain definitive evidence. There may be strong indicators of illegal hiring practices, but it is unlikely that it is definitive, absolute evidence. The employer may have fully complied with federal laws in hiring practices, and they may feel they are in compliance with the laws.

\section{POSSIBLE ILLEGAL ACTS}

To further the discussion, the auditor has a responsibility to search for illegal acts. The AICPA Professional Standards section AU 317, Illegal Acts by Clients, addresses the auditor's responsibilities for detecting illegal acts. The standards define illegal acts as violations of laws or governmental regulations. Illegal acts by clients are acts attributable to the entity whose financial statements are under audit or acts by management or employees acting on behalf of the entity. Illegal acts by clients do not include personal misconduct by the entity's personnel unrelated to their business activities.

If the client knowingly hires illegal employees, this behavior would be considered an illegal act by the client and would require additional audit procedures to determine the extent of the problem and possible financial impact on the financial statements.

During the course of the audit, the auditor may identify an investigation by a governmental agency, an enforcement proceeding, or payment of unusual fines or penalties or violations of laws or regulations cited in reports of examinations by regulatory agencies that have been made available to the auditor. Even in cases where the employer has been identified as employing illegal employees, the auditor is going to have difficulty determining whether the client has knowingly hired illegal employees. It may be known that the client has hired illegal employees, but the knowledge that it was done knowingly will be a challenge for the auditor to determine. In most cases, the client does its best to comply with the federal laws when hiring employees.

\section{MANAGEMENT INTEGRITY ISSUES}

Significant questions about management's integrity arise when management knowingly hires illegal employees. The auditor would need to consider the implications of management's integrity if he or she felt the client was knowingly hiring illegal workers. In many of these cases, the client believes it is justified in hiring illegal status employees. But, if they are justifying this action, wouldn't they justify other fraudulent or illegal acts? The auditor should consider the implications of an illegal act in relation to other aspects of the audit, particularly the 
reliability of representations of management. The implications of particular illegal acts will depend on the relationship of the perpetration and concealment, if any, of the illegal act to specific control procedures and the level of management or employees involved. In some circumstances, management's behavior would create enough uncertainty about management's representations that the auditor may consider withdrawing from the engagement. If the auditor believes that the client is likely to hire illegal employees or when the client operates in an industry that is highly likely to hire illegal immigrants, such as the meat packing, construction, agricultural, leisure (hotels), and cleaning services industries, the auditor would have an obligation to expand the audit to search for possible illegal acts and to consider the potential financial implications. In the normal course of the audit, the auditor performs procedures that might bring illegal acts to the attention of the auditor.

These procedures would include reading board minutes; inquiring of the client's management and legal counsel concerning litigation, claims, and assessments by relevant regulatory agencies; performing substantive tests of details of transactions or balances of payroll and payroll taxes. The auditor may expand the audit procedures to test the organization's processes for hiring and following up on social security number discrepancy reports. Furthermore, the auditor should make inquiries of management concerning the client's compliance with laws and regulations. Where applicable, the auditor should also inquire of management concerning:

- $\quad$ The client's policies relative to the prevention of illegal acts.

- $\quad$ The use of directives issued by the client and periodic representations obtained by the client from management at appropriate levels of authority concerning compliance with laws and regulations.

The auditor should also obtain written representations from management concerning the absence of violations or possible violations of laws or regulations whose effects should be considered for disclosure in the financial statements or as a basis for recording a loss contingency. However, the auditor need perform no further procedures in this area absent specific information concerning possible illegal acts.

In some of the reported ICE cases, such as the Swift Company raids, the employees were found to have used illegal or fraudulent documents to be hired, but the audit client had used the appropriate hiring processes. The company was considered in compliance with the federal hiring laws. Thus, the employees have violated the law and not the audit client.

However, in these circumstances, the client has two potential issues. The first issue of concern is whether the organization faces any potential illegal act violations, which may result in potential fines and penalties. The second issue is the losses or potential losses that may result from the disruption of business.

\section{FINANCIAL UNCERTAINTIES WITH RESPECT TO ILLEGAL EMPLOYMENT}

From the discussion with management and the results of other audit procedures, evidence may exists that there is a contingent liability that exists. The auditor should consider the effect of the illegal act on the amounts presented in financial statements including contingent monetary effects, such as fines, penalties and damages. Loss contingencies resulting from illegal acts that may be required to be disclosed should be evaluated in the same manner as other loss contingencies. Furthermore, possible business interruptions and other losses might occur if ICE performed raids, so appropriate financial statement disclosures would be necessary.

\section{Communication with Those Charged With Governance}

The auditor should assure himself that those charged with governance are adequately informed with respect to illegal acts that come to the auditor's attention. The auditor need not communicate matters that are clearly inconsequential and may reach agreement in advance with the audit committee on the nature of such matters to be communicated. The communication should describe the act, the circumstances of its occurrence, and the effect on the financial statements. Senior management may wish to have its remedial actions communicated to the audit committee simultaneously. Possible remedial actions include disciplinary action against involved personnel, seeking restitution, adoption of preventive or corrective company policies, and modifications of specific control activities. If senior management is involved in an illegal act, the auditor should communicate directly with those charged with 
governance. The communication may be oral or written. If the communication is oral, the auditor should document it.

\section{Effect on the Auditor's Report}

If the auditor concludes that an illegal act has a material effect on the financial statements, and the act has not been properly accounted for or disclosed, the auditor should express a qualified opinion or an adverse opinion on the financial statements taken as a whole, depending on the materiality of the effect on the financial statements.

If the auditor is precluded by the client from obtaining sufficient appropriate audit evidence to evaluate whether an illegal act that could be material to the financial statements has, or is likely to have, occurred, the auditor generally should disclaim an opinion on the financial statements.

If the client refuses to accept the auditor's report as modified for the circumstances described in the report, the auditor should withdraw from the engagement and indicate the reasons for withdrawal in writing to those charged with governance.

Disclosure of an illegal act to parties other than the client's senior management and those charged with governance is not ordinarily part of the auditor's responsibility, and such disclosure would be precluded by the auditor's ethical or legal obligation of confidentiality, unless the matter affects his opinion on the financial statements. The auditor should recognize, however, that in the following circumstances a duty to notify parties outside the client may exist:

- When the entity reports an auditor change under the appropriate securities law on Form 8-K.

- To a successor auditor when the successor makes inquiries to the predecessor auditor.

- In response to a subpoena.

- $\quad$ To a funding agency or other specified agency in accordance with requirements for the audits of entities that receive financial assistance from a government agency

Because potential conflicts with the auditor's ethical and legal obligations for confidentiality may be complex, the auditor may wish to consult with legal counsel before discussing illegal acts with parties outside the client.

\section{CONCLUSION}

The auditor may have an obligation to expand audit procedures to investigate the possibility of illegal hiring practices. When the client is operating in an area or industry where illegal employees are commonly used, then the auditor should use an attitude of professional skepticism and beware of illegal employees being used by the company. Inquiries and observations procedures may indicate potential illegal hiring practices. Also, discussions with management and other employees should be performed as well as a thorough review of board minutes. The procedures performed by the auditor in gaining an understanding of the entity and its environment as well as in the search for illegal acts may identify situations where the hiring of illegal employees is a possibility. An attitude of professional skepticism should prevail in all audits.

However, asking the auditor to be responsible for detecting illegal employees is a far reach. This is management's responsibility. If management is honest about their actions, the auditor may obtain knowledge about the illegal acts. The real resolution of this issue will come through legislation being passed by the federal government.

\section{AUTHOR INFORMATION}

Ronald O. Reed, Ph.D., CPA., Dr. Reed has been a Professor of Accounting at the University Northern Colorado for twenty years. He teaches in the auditing and managerial accounting areas. He is very involved in the accounting profession. He is joining the Board of Directors for the Colorado Society of CPAs and serves on the Board of Directors for the Colorado Chapter of FEI. He has been the past President of the Colorado Chapter of FEI and 
served on the Western Area FEI Board. He has published extensively on accounting education and practical accounting and auditing issues.

Karen Forrest Turner, Ph.D., CPA: Dr. Turner's teaching fields include fraud, financial accounting, auditing and accounting communications. She currently serves on the Colorado State Board of Accountancy and NASBA's Education Committee. Her research interests are in accounting education and communications, auditing, and fraud.

Allen McConnell, MS, CPA, Allen W. McConnell, Professor of Accounting, joined the University of Northern Colorado business faculty in 1968 after earning his BSBA and MS in Accounting at the University of North Dakota. Prior to coming to UNC, Allen taught at Dakota State College and has served as a visiting professor in Bemidji State University. Allen has worked for several CPA firms in North Dakota and Colorado. McConnell's primary teaching responsibility are in the financial accounting areas, but has taught in the areas of auditing, governmental, and managerial accounting. He has served as Department Chair for fourteen years.

\section{REFERENCES}

1. American Institute of CPAs, AICPA Resource Library On-line: AICPA Professional Standards, 2008.

2. Immigration and Custom Enforcement (ICE) Agency, www.ice.gov, 2008.

\section{Figure 1: I-9 Form (next 3 pages)}




\section{INSTRUCTIONS
INTS}

Employment Eligibility Verification

\section{PLEASE READ ALL INSTRUCTIONS CAREFULLY BEFORE COMPLETING THIS FORM.}

Anti-Discrimination Notice. It is illegal to discriminate against any individual (other than an alien not authorized to work in the U.S.) in hiring, discharging, or recruiting or referring for a fee because of that individual's national origin or citizenship status. It is illegal to discriminate against work eligible individuals. Employers CANNOT specify which document(s) they will accept from an employee. The refusal to hire an individual because of a future expiration date may also constitute illegal discrimination.

Section 1- Employee. All employees, citizens and noncitizens, hired after November 6, 1986, must complete Section 1 of this form at the time of hire, which is the actual beginning of employment. The employer is responsible for ensuring that Section 1 is timely and properly completed.

Preparer/Translator Certification. The Preparer/Translator Certification must be completed if Section 1 is prepared by a person other than the employee. A preparer/translator may be used only when the employee is unable to complete Section 1 on his/her own. However, the employee must still sign Section 1 personally.

Section 2 - Employer. For the purpose of completing this form, the term "employer" includes those recruiters and referrers for a fee who are agricultural associations, agricultural employers or farm labor contractors.

Employers must complete Section 2 by examining evidence of identity and employment eligibility within three (3) business days of the date employment begins. If employees are authorized to work, but are unable to present the required document(s) within three business days, they must present a receipt for the application of the document(s) within three business days and the actual document(s) within ninety (90) days. However, if employers hire individuals for a duration of less than three business days, Section 2 must be completed at the time employment begins. Employers must record: 1) document title; 2) issuing authority; 3) document number, 4) expiration date, if any; and 5) the date employment begins. Employers must sign and date the certification. Employees must present original documents. Employers may, but are not required to, photocopy the document(s) presented. These photocopies may only be used for the verification process and must be retained with the I-9. However, employers are still responsible for completing the l-9.

Section 3 - Updating and Reverification. Employers must complete Section 3 when updating and/or reverifying the I-9. Employers must reverify employment eligibility of their employees on or before the expiration date recorded in Section 1 . Employers CANNOT specify which document(s) they will accept from an employee.

- If an employee's name has changed at the time this form is being updated/reverified, complete Block $A$.

- If an employee is rehired within three (3) years of the date this form was originally completed and the employee is still eligible to be employed on the same basis as previously indicated on this form (updating), complete Block B and the signature block.

- If an employee is rehired within three (3) years of the date this form was originally completed and the employee's work authorization has expired or if a current employee's work authorization is about to expire (reverification), complete Block $\mathrm{B}$ and:
- examine any document that reflects that the employee is authorized to work in the U.S. (see List A or C),

- record the document title, document number and expiration date (if any) in Block $\mathrm{C}$, and

- complete the signature block.

Photocopying and Retaining Form I-9. A blank I-9 may be reproduced, provided both sides are copied. The Instructions must be available to all employees completing this form. Employers must retain completed I-9s for three (3) years after the date of hire or one (1) year after the date employment ends, whichever is later.

For more detailed information, you may refer to the Department of Homeland Security (DHS) Handbook for Employers, (Form M-274). You may obtain the handbook at your local U.S. Citizenship and Immigration Services (USCIS) office.

Privacy Act Notice. The authority for collecting this information is the Immigration Reform and Control Act of 1986 , Pub. L. 99-603 (8 USC 1324a).

This information is for employers to verify the eligibility of individuals for employment to preclude the unlawful hiring, or recruiting or referring for a fee, of aliens who are not authorized to work in the United States.

This information will be used by employers as a record of their basis for determining eligibility of an employee to work in the United States. The form will be kept by the employer and made available for inspection by officials of the U.S. Immigration and Customs Enforcement, Department of Labor and Office of Special Counsel for Immigration Related Unfair Employment Practices.

Submission of the information required in this form is voluntary. However, an individual may not begin employment unless this form is completed, since employers are subject to civil or criminal penalties if they do not comply with the Immigration Reform and Control Act of 1986.

Reporting Burden. We try to create forms and instructions that are accurate, can be easily understood and which impose the least possible burden on you to provide us with information. Often this is difficult because some immigration laws are very complex. Accordingly, the reporting burden for this collection of information is computed as follows: 1) learning about this form, 5 minutes; 2) completing the form, 5 minutes; and 3 ) assembling and filing (recordkeeping) the form, 5 minutes, for an average of 15 minutes per response. If you have comments regarding the accuracy of this burden estimate, or suggestions for making this form simpler, you can write to U.S. Citizenship and Immigration Services, Regulatory Management Division, 111 Massachuetts Avenue, N.W.,

Washington DC 20520 OMR No 1615-0047

NOTE: This is the 1991 edition of the Form I-9 that has been rebranded with a current printing date to reflect the recent transition from the INS to DHS and its components. 
Department of Homeland Security

U.S. Citizenship and Immigration Services

OMB No. 1615-0047; Expires 03/31/07

Please read instructions carefully before completing this form. The instructions must be available during completion of this form. ANTI-DISCRIMINATION NOTICE: It is illegal to discriminate against work eligible individuals. Employers CANNOT specify which document(s) they will accept from an employee. The refusal to hire an individual because of a future expiration date may also constitute illegal discrimination.

\begin{tabular}{|c|c|c|}
\hline Print Name: Last & Middle Initial & Maiden Name \\
\hline Address (Street Name and Number) & Apt. \# & Date of Birth (month/day/year) \\
\hline State & Zip Code & Social Security \# \\
\hline $\begin{array}{l}\text { I am aware that federal law provides for } \\
\text { imprisonment and/or fines for false statements or } \\
\text { use of false documents in connection with the } \\
\text { completion of this form. }\end{array}$ & \multicolumn{2}{|c|}{$\begin{array}{l}\text { I attest, under penalty of perjury, that I am (check one of the following): } \\
\begin{array}{|l}\square \text { A citizen or national of the United States } \\
\square \text { A Lawful Permanent Resident (Alien \#) A } \\
\square \text { An alien authorized to work until }\end{array}\end{array}$} \\
\hline
\end{tabular}

\begin{tabular}{|c|c|}
\hline \multicolumn{2}{|l|}{ Employee's Signature } \\
\hline \multicolumn{2}{|c|}{$\begin{array}{l}\text { Preparer and/or Translator Certification. (To be completed and signed if Section } 1 \text { is } \\
\text { other than the employee.) I attest, under penalty of periury, that I have assisted in the completion o } \\
\text { of my knowledge the information is true and correct. }\end{array}$} \\
\hline Preparer's/Translator's Signature & Print Name \\
\hline
\end{tabular}

Section 2. Employer Review and Verification. To be completed and signed by employer. Examine one document from List A OR examine one document from List $B$ and one from List $C$, as listed on the reverse of this form, and record the title, number and expiration date, if any, of the document(s).

List A
Document title:
Issuing authority:
Document \#:
$\quad$ Expiration Date (if any):
Document \#:
Expiration Date (if any):

CERTIFICATION - I attest, under penalty of perjury, that I have examined the document(s) presented by the above-named employee, that the above-listed document(s) appear to be genuine and to relate to the employee named, that the employee began employment on (month/day/year)__and that to the best of my knowledge the employee is eligible to work in the United States. (State employment agencies may omit the date the employee began employment

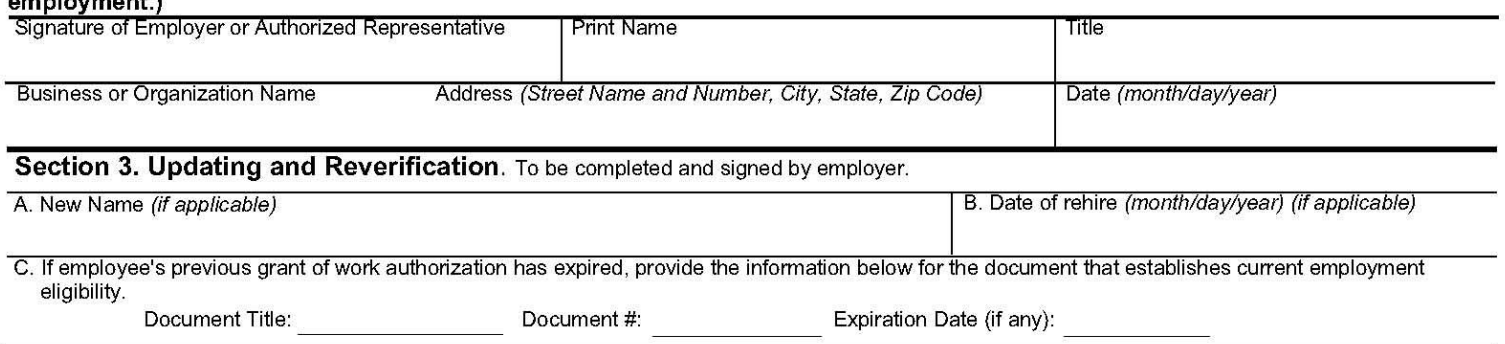

I attest, under penalty of perjury, that to the best of my knowledge, this employee is eligible to work in the United States, and if the employee presented document(s), the document(s) I have examined appear to be genuine and to relate to the individual.

\begin{tabular}{l|l|l}
\hline presented document(s), the document(s) I have examined appear to be genuine and to relate to the individual. \\
\hline Signature of Employer or Authorized Representative & Date (month/day/year) & Form I-9 (Rev. 05/31/05)Y Page 2 \\
\hline $\begin{array}{l}\text { NOTE: This is the 1991 edition of the Form I-9 that has been rebranded with a } \\
\text { current printing date to reflect the recent transition from the INS to DHS and its } \\
\text { components. }\end{array}$ &
\end{tabular}




\section{LISTS OF ACCEPTABLE DOCUMENTS}

LIST A

Documents that Establish Both Identity and Employment Eligibility

1. U.S. Passport (unexpired or expired)

2. Certificate of U.S. Citizenship (Form N-560 or N-561)

3. Certificate of Naturalization (Form N-550 or N-570)

4. Unexpired foreign passport, with 1-551 stamp or attached Form 1-94 indicating unexpired employment authorization

5. Permanent Resident Card or Alien Registration Receipt Card with photograph (Form l-151 or $\mid-551)$

6. Unexpired Temporary Resident Card (Form 1-688)

7. Unexpired Employment Authorization Card (Form (-688A)

8. Unexpired Reentry Permit (Form 1-327)

9. Unexpired Refugee Travel Document (Form 1-571)

10. Unexpired Employment Authorization Document issued by DHS that contains a photograph (Form 1-688B)

\section{LIST B}

Documents that Establish Identity

OR

1. Driver's license or ID card issued by a state or outlying possession of the United States provided it contains a photograph or information such as name, date of birth, gender, height, eye color and address

2. ID card issued by federal, state or local government agencies or entities, provided it contains a photograph or information such as name, date of birth, gender, height, eye color and address

3. School ID card with a photograph

4. Voter's registration card

5. U.S. Military card or draft record

6. Military dependent's ID card

7. U.S. Coast Guard Merchant Mariner Card

8. Native American tribal document

9. Driver's license issued by a Canadian government authority

For persons under age 18 who are unable to present a document listed above:

10. School record or report card

11. Clinic, doctor or hospital record

12. Day-care or nursery school record
LIST C

Documents that Establish

AND Employment Eligibility

1. U.S. social security card issued by the Social Security Administration (other than a card stating it is not valid for employment)

2. Certification of Birth Abroad issued by the Department of State (Form FS-545 or Form DS-1350)

3. Original or certified copy of a birth certificate issued by a state, county, municipal authority or outlying possession of the United States bearing an official seal

4. Native American tribal document

5. U.S. Citizen ID Card (Form 1-197)

6. ID Card for use of Resident Citizen in the United States (Form 1-179)

7. Unexpired employment authorization document issued by DHS (other than those listed under List A)

Illustrations of many of these documents appear in Part 8 of the Handbook for Employers (M-274) 